\title{
江戸時代の京都の指物師と御所のかかわり RELATION BETWEEN CABINETMAKER AND IMPERIAL PALACE IN KYOTO OF EDO PERIOD
}

\author{
丸山俊明*
}

\author{
Toshiaki MARUYAMA
}

\begin{abstract}
In an architectural space of Japan, there was a part supported by the traditional craft. However, it was basic that the traditional craft handed down many of technologies by the home. Therefore, material that showed the system of production, the form of business, and the relation to the society was a little and the previous work was also few, and consequentially little. In Kyoto of Edo period, in such and this thesis take up the material spread to the house of the cabinetmaker to make the imperial palace a customer. And, it is clarified to the cabinetmaker of Kyoto to have divided into the person who always goes in and out to the imperial palace and the person who was tendering at each work.
\end{abstract}

Keywords : Kyoto, Cabinetmaker, Imperial palace, craft, Fine and applied art 京都，指物師，御所，工芸，美術工芸

\section{1. はじめに}

日本の伝統的な建築空間は、例えば古代の寝殿造で舗設具の配置 が重要な意味を持ち、大臣大饗等の年中行事で役割を果たしたこと が川本重雄氏の研究によって明らかにされているように注1)、多くの 伝統工芸が関わって形成された。そうすると、直接的に建築に関わ った大工等の職人の営業形態を伊藤鄭爾氏や日向進氏らが研究課題 とされたように注2)、工芸職人の生産体制や営業形態、社会的な位置 付けも、日本建築史分野においても検討すべき課題と思われる。

しかしながら、工芸品には建築系道具雛形について永田恵子・岡 本真理子・河田克博・麓和善・仙田満・内藤昌・高木真人ら各氏の 精緻な成果があっても注3)、工芸職人の先行研究は管見に入らない。

この状況の背景には、関連史料が少ないことがある。近世社会に は相当数の工芸職人が予想されるが、多くの家蔵文書がある京都で も、工芸関係の一次史料は少ない。その中で、御所の「御菓子御用」 の虎屋の社史注4)に、「寄宿免除」を受けた江戸時代の営業形態が紹 介されている。また池田好信氏ら京都府立総合資料館歴史資料課の 『御用砂子屋美濃地仲間文書』に関する史料紹介注5)では、砂子（金 簿・銀䈃を細かくした切䇴の一種）を扱う業者には禁裏御所や幕府 と関連を持つ御用砂子屋と、町人相手の平砂子屋がいたこと等が明 らかにされている。しかし、安道永氏が二次史料によって絵師の居 住動向を検討されたように注 6 、 、公開された一次史料の数は限られて おり、上記課題の検討にはさらなる史料収集と分析が課題であった。 そこに今回、京都府立総合資料館所蔵『船屋 (久米家) 太兵衛家 文書』に関連文書が多数含まれていることが判明したので、本論で 取り上げて、京都特有の顧客である御所との関係を検討する。

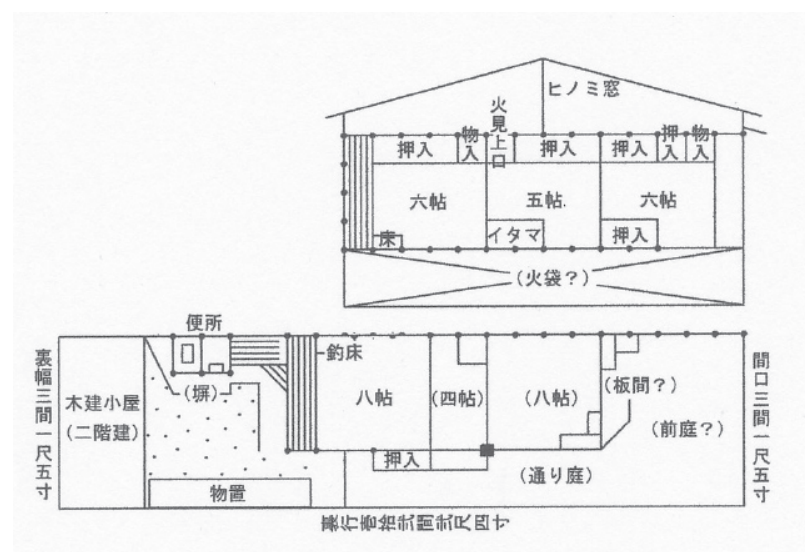

図 1 船屋太兵衛家平面 (上段 : 2 階と屋根形状、下段 : 1 階と配置)

同資料館の山田洋一氏によれば、久米家は「船屋」の屋号をもち、 当主は代々「太兵衛」の名前で寛永（1624～44）加明治中頃の廃 業まで、西堀川通出水通下ルの四町目で禁裏御所や公家衆に白木作 りの道具類や御所等の池で使う「御船(みふね)」を調進する指物師 として営業していた注7)。この船屋が残した史料群が『船屋太兵衛家 文書』である。多様な内容をみるが、例えば明治初頭の沽券状や指 図には間口も裏幅も「間口三間一尺五寸」で「裏行拾武間武尺四寸」 の敷地に「瓦フ扡二階建」の「本宅」や「木建小屋」（材料置場の可 能性があるが正確には不明）の配置や、前庭をもち坪庭・玄関はな い間取りが読み取れる (図 1、図中（）内は筆者)。つまり二条城近 くで (図 $2 \star$ 位置)、典型的な町家が営業場所であったことが分る。

\footnotetext{
* 住環境文化研究所 学博

Culture and Life Environment Laboratory, Ph. D.
} 
また明和 3 年（1766）12 月 6 日に「沽券改」を受けたことを記す 史料 (「家屋敷事」) や、明和 4 年（1767）11月にも「沽券改」を受 けたとする史料（「家屋敷事」）にも、同じ場所に「壱軒役、表口三 間壱尺五寸、裏行拾武間武尺四寸」とあり、少なくとも江戸後期の 敷地形状に变化はなかった。もっとも明治新政府宛の「家屋敷之事」 には「壱ヶ所半軒役、西堀川通出水下ル四町目東側、表口三間壱尺五 寸、裏行六間半」とあるが、これには以下のように記されている。

右者寛永度上洛之節、当町道幅御取広ヶ二付、西側居宅表側二而 三間通建物取払被仰付、往還二相成依而、右以来居宅向ひ地先 川端江建物仕候義御聞済被成下追々奉願、既在之建物仕所持罷 在候、然処、今般右地所表側鬥川縁迄、沽券地二御赦免被成下

候様奉願候、如願之通、御聞届被成下即書面間数之通二而向後 半軒役相勤所持仕度、新沽券状二御割印奉願上候、船屋太兵衛

寛永 3 年（1626） 8 月の将軍家光上洛時、船屋の前の西堀川通が 拡幅とある。杉森哲也によれば、翌 9 月の後水尾天皇の二条城行幸 で行幸経路になるので注8)、それとの関係が想像される。そして表側 三間を失った船屋は背面の堀川側に建物を建て、維新後の新政府の 沽券改において所有確認を願ったのである。内容の真偽や申請結果 は明らかでないが、遅くとも寛永期には船屋が当地に居住し、一応 寛永以降は敷地形状に変化がなかったことを示寸史料となる。また 寛文 5 年 (1665）の『京雀』注9)に「ほり川通、ほり川四町め、此町 は桶・井づつ・つるべ・水船などをつくりてあきなふ」とあり、貞 享 2 年 (1685) の『京羽二重』注10) にも「西堀川通、此通諸職物、 桶、井筒、水船類」とあって、船屋の位置する辺りは確かに「水舟」 と称される船や水関連の指物を扱う指物師の居住地とされている。

もつとも『船屋太兵衛家文書』では、水舟の修理・新調費用の記 録や図面に限らず、朝廷関係の婚礼調度や、龍吐水等の消防道具を 入札した際の記録、或いは箱や膳といった指物絵図も多く含まれて おり、それよりむしろ、大部分が御所関係である点が特徵的である。

江戸時代の御所は、「築地之内」と称される地域に禁裏御所（天皇 御座所）や仙洞御所、女院御所が置かれ、周囲は公家屋敷群が埋め て、それらの土塀や九門が周辺の町家群と隔てた。京都の工芸職人 には最重要の顧客であり、特に関係の深い者は御所から、町人義務 の公役を免除される「諸役免除」や、上洛武士の受け入れ義務を免 除される「寄宿免除」という特権を付与された。筆者は「諸役免除」 を受けた町人が火消人足への屋根提供義務も免れるとして自宅の大 屋根軒先に長板を掲げたこと、これに対し消防組織でもある所司代一 町奉行所体制は「御札改」を繰り返し、根拠を失った者から剥奪、 代わりに入った者は菊紋入の御用提灯付与に変わる場合が多かった こと、ただしそれも御所役人が火災時に吊ることを指示していて火 消人足の拒否機能は残った可能性が高いことを指摘した注11)。徳川 政権が命じた町人義務を、一部でも御所が免除するのは京都特有の 二重行政であり、それを受けた工芸職人も特殊な立場であったこと になる。そして『船屋太兵衛家文書』には提灯付与に関する史料が あるので、本論では船屋と御所との関係を示す史料を中心に検討し、 御所が存在する京都の指物師特有の営業形態の一端を明らかにする。

\section{2. 安永期の史料にみる船屋と御所の関係}

安永 3 年 (1774) 8 月、徳川幕府は朝廷の不正経理を糾弾して、 地下官人 40 人を処分、経理に関わった京都代官小堀数馬邦直も叱責
した。『船屋太兵衛家文書』の中にも、この事件について、以下のよ うに記す紙片を付けて一括りにした史料群がある。

安永二年巳十月十五日、御所樣役人ほうとうの節、西役所山村 信濃守様へ召出され、同月廿三日返答事案紙書面

処分前年の安永 2 年（1773） 10 月、船屋太兵衛は西町奉行山村信 濃守良旺から召喚され、御所役人の放蕩に関し尋問を受けたらしい。 同月 23 日に返答書提出とあり、御所出入の工芸職人側も調查対象に なったことがわかるが、船屋は処分実施の安永 3 年 8 月に疑惑が晴 れたとの書き込みを残す（「午八月廿六日七日両日万事此義相済」）。

そしてこの史料群には、船屋と御所役人との関係や業務経歴が窥 える。まず西町奉行への返答書の可能性が高い「就御尋以書面申上 候」には、「走・水船・指物商売之者」と自称して以下を記している。

一、私儀、禁裏御修理方、仙洞御所御修理方、新女院御所修理 方、右之通、臨時御用相勤申候所、禁裏御所、去辰年中、 御所臨時御用代銀、私受取節百目二而九分多不足御座候 仙洞御所、去辰年中、御所臨時御用代銀、私受取節百目二 而九分一多不足御座候、新女院御所、去辰年中、御所臨時 御用代銀、私受取節百目二而、九分一多不足御座候

一、定式御用八三御所共相勤不申候

禁裏・仙洞・新女院の三御所の「臨時御用」を務めているが、「定 式御用」は務めないとする。船屋太兵衛家文書』に御所関係の入札 記録が多いことを考え合わせると、入札を経た業務が「臨時御用」 であり、随時受注の特命業務が「定式御用」と推定される。よって 御所御用の指物師は随時受注と入札参加に分かれ、御所との関係が より深いのは前者、当時の船屋太兵衛は後者、と考えられる。また 金額については、より詳細に記す以下の返答書が残されている。

禁裏御所様御用代銀高

$$
\begin{aligned}
& \text { 明和三年戌七月归半年高、銀主八拾八多 } \\
& \text { 亥年壱ヶ年メ高、銀 } \\
& \text { 三百目壱分 } \\
& \text { 子年壱ヶ年メ高、銀 } \\
& \text { 百九拾目壱分 } \\
& \text { 丑年壱ヶ年 } \nsim \text { 高、銀 } \\
& \text { 七拾武多六分 } \\
& \text { 寅年壱ヶ年 高、銀 } \\
& \text { 武百六拾八多八分 } \\
& \text { 卯年壱ヶ年 } \nsim \text { 高、銀 } \\
& \text { 武百七拾壱多六分 } \\
& \text { 辰年壱ヶ年メ高、銀 } \\
& \text { 一貫式百武拾九斥五分 } \\
& \text { 巳年壱ヶ年メ高、銀 } \\
& \text { 三百五拾壱多五分 }
\end{aligned}
$$

是迄都合、武貫七百廿武多二分

仙洞御所様御用代銀高

$$
\begin{aligned}
& \text { 明和七年 寅年メ高、銀拾四斥 } \\
& \text { 卯年风高、銀 壱百五拾壱必九分 } \\
& \text { 辰年メ高、銀参拾五多五分 } \\
& \text { 巳年风高、銀 廿五多武分 }
\end{aligned}
$$

是迄都合、武百武拾六多六分

右之通是迄都合銀子頂戴仕相違無御座候

これをみると、町奉行所一の召喚の前年（辰年、安永元年 1772） に船屋と禁裏御所との取引が一桁大きくなっている。そのためなの か、取引額や御所役人との関係についてさらに記す返答書がある。

一、禁裏御所、辰年之年中御用高一貫式百九多五分 右八百目二付壱多程示之く御座候、尤少々過銀之在々之時も 御座候、何連二も其侭二修理職御役所へ相納御通、表銀高、 都合其時請取申候 
一、仙洞御所、辰之年御用高三拾斥七分、右八武分程不足在 之、過銀無御座候

一、新女院御所辰年中御用高、四百三拾六多七分、右八不足 并過銀等一切無御座候

右何連御所役人中へ年中差定川送物八、二季扴祝儀、極月牛蒡 又八鱈壱本或八みぶな之類遣申候（略）平生八一向音物等遣之 不申、且又暑中之音物等も遣不申 (後略)

禁裹御所に対し「百目」つまり 100 多につき 1 多「ふそく」と記 す正確な意味は明らかでないが、受取り過ぎを意味するらしい「過 銀」と対比されるので、支払関係に多少曖昧な部分を認めている。 また御所役人との贈答関係については、祝儀（「二季扫祝儀」、1 年 に 2 回渡寸意味か)や 12 月の牛蒡·鱈・壬生菜等を届ける程度とし、 入札参加資格を持つだけの「臨時御用」の船屋でもこの程度の贈答 は行っていたことが分かる。それでも普段は贈物（「音物」）はしな いと記すので、この程度は社会常識の範疇であったのだろう。

また御所との関係が何時から始まったのかにも、返答書がある。 就御尋乍恐口上書 指物商売

一、禁裹御所様江御出入仕、数代御用相勤来归由、申伝承 知仕候得共、何之頃归之申年月難承知御座候、貞享・元 禄以来御用寸法・雛型等所持仕罷在候、御用相勤来》候

一、仙洞御所様江御出入仕、数代御用相勤来》候由、申伝承 知仕候得共、何之頃归と申年月難承知御座候、元禄以来 御用寸法・雛型等所持仕罷在候、御用相勤来》候

「右申上候安永三年頃、天野近江守様御役人中様」との書き込み があり、所司代配下で禁裏付の幕府役人（天野近江守正景）への返 答書である。禁裏御所・仙洞御所とも出入開始時期は不明としなが ら貞享・元禄期には記録ありとし、船屋の臨時御用は遅くとも 17 世紀末に始まり、事件までに 1 世紀近く経過していた。そして調査 対象の安永元年に取引額が増大した船屋であったが、疑惑は晴れた から今まで通り御用を務めたいと願う「乍恐口上書」が残っている。

一、私義、去ル八月西御役所一被為召出二而、私義済方何之 御懸念無之趣二而過料等も不被仰付相済罷帰り申侯、勿論 其以、不相替御用被為仰付、相勤来归居申候義二御座候、 何卒御慈悲を以不相替御用被為仰付被下置候八、難有可 奉存候、以上、安永四年未正月廿二日、舟屋太兵衛

処分翌年の安永 4 年 (1775) 正月 22 日の文書である。これは同日 に「仙洞御所、古居七之助・西川是蔵・山本小左衛門」から、これ からも御用を希望するのか否かを届け出るよう命じられ(「去ル午八 月御所向役人御仕置被仰付候以後西御役所・被召出、済方之趣且又過 料被仰付趣、又者其儀二不及候趣勿論、此以後御用相勤可申、或否之 義以今明日中可被申出候」)、これに答えた文書である。このように 連座を免れた船屋太兵衛は、さらに翌月の安永 4 年 2 月、「仙洞御所 御役人中」へ以下のような「乍恐奉申上口上書」を提出している。

一、私儀、御修理職方二而、水舟・走 $\cdot$ 指物類御用被仰付候 者二御座候、此度御值段相改义、引下斤候様被仰付奉畏候、 私相勤申御用、定式御值段と申義無御座候二付、是迄御 用度々積書差上、御吟味之上被仰付、相勤来候、猶又 此以後御用之節八御值段厳敷引下積書相遣候、以上

御所の「御修理職方」に「指物御用」で出入する者とした上で、 「御值段相改义、引下个」命令に対し、「是迄御用度々積書差上、御吟
味之上被仰付、相勤来候」として、自らの御所御用に「定式御值段」 はないとする。それが「臨時御用」の営業形態とすると、先にも推 定した様に随時受注の特命業務が「定式御用」で、そこには「定式 御値段」があったことになる。それへの引下げ命令は、不正経理に 流れた上積み分を排除する御所役人の目的が推定される。

以上のように船屋太兵衛家は、入札資格を持つ臨時御用の指物師 として 1 世紀近く三御所一出入し、御所役人と社会常識の範囲で関 係を持っていた。なお事件後も、御所付の幕府役人による出入業者 の監視は続いたようで、安永 5 年（1776）11月の「天野近江守椂御 役人中」宛の「乍恐向上書」にも次のように記されている。

一、私儀、御所様江前々归御出入御用等相勤来侯得共、私 居宅表二御用札并暖篻等一切無御座候、依之乍恐御断奉 申上候、以上、安永五年申十一月

御所との関係を強調する札や暖笠を表に出していないか問い合わ せがあったようで、使用していないと返答している。それでも『船 屋太兵衛家文書』には、その後も船屋にとって三御所が重要な顧客 であったことを示寸文書が残されているので、次節で取り上げる。

\section{3. 臨時御用から定式御用へ、立場の変化を窥わせる史料}

文化 4 年（1807） 8 月に船屋太兵衛が御所役人へ宛てた「乍恐口 上書」には、次のように記されている。

御道具木地方御用、私儀前々归被為仰付相勤来川、難有仕合奉 存候、然儿処、今般親王様御用木地方、不相替為仰付被下置候 様、奉願上候、何卒御慈悲二仕、右願之通御済被下被為仰付下 候八、、難有仕合奉存候、以上、

船屋は以前から「御道具木地方御用」つまり指物の御用を務めて いるとし、同年の「親王 (天皇の兄弟・皇子)」に関わる御用も、そ れまで同様に受注を願っている。ここで注意すべきは、この内容は 入札参加資格だけを持つ臨時御用というよりも、特命業務を随時受 注する定式御用の立場のように読み取れる点である。そうすると、 この時期までに船屋は定式御用の立場を得たことになる。その経緯 を伝える史料は現時点で見当たらないが、この頃から幕末にかけて、 ほぼ同様の文書が数多く残されている。例えば文化 11 年 (1814) の 「御修理職御役所」宛の「乍恐奉願上口上書」にも次のようにある。 御出入御用向共被為仰付、御慈悲之上、乍恐代々無滞相勤、冥 加至極難有仕合奉存候、然几処、御息所様御出入御用向、先例 之通二為仰付被下候様奉願上候、乍恐御憐憫を以、右願之通被 為仰付被下候八、渡世も手広二相成、猶又何連も先例在候ものと も二候工八、外聞等迄誠二広大二御慈悲と難有仕合奉存候、以上

木子

木子作太夫 大黒屋市左衛門 松屋新兵衛

口法藤兵衛 桧皮屋貞七 舟屋太兵衛 山崎屋五兵衛 錺師種兵衛 塗師七郎衛門

口師六兵衛 
伊勢屋伊兵衛

瓦師源三郎

永野七右衛門

三年屋与兵衛

一部読取不能の個所があり、またいずれの御所宛かも分らないが、 「御息所（皇子・皇女を生んだ女御・更衣）」に関わる御用受注を願 つており、やはり定式御用の立場が窥える。また連署者のうち冒頭 2 名は「京十人棟梁」の流れを引く木子組棟梁注12) と推定され、他の 「桧皮屋」「錺師」「塗師」「瓦師」も建築関連と推定される。よって これらと連署する船屋太兵衛も、下京を得意場とする木子組に指物 師として加わっていたことが窥える。もっとも現時点では他に同様 文書が見当たらないので、集団成立の時期や経緯は明らかでない。

以上、船屋太兵衛は、文化 4 年（1807）の時点では定式御用の立 場にあった可能性が高い。この点をふまえて次節では、御所との関 係で船屋が御用提灯を付与された経緯や相続時の問題を取り上げる。

\section{4. 御用提灯と非常札の付与}

船屋太兵衛が御所から御用提灯を付与されていたことは、例えば 天保 14 年（1843）の町奉行所宛の「乍恐口上書」に読み取れる。

御用之書記有之候

釣提灯壱張

箱提灯壱張

弓張提灯壱張

非常札壱枚

右者、私父太兵衛義、御所様江御出入仕、御常式御指物御用相 勤候二付、書面之通、御提灯 - 非常札共頂戴罷在候処、及老年 相勤退身仕、私義相続仕、右御用是迄之通私江被仰付相勤候時、 右提灯非常札共其侭御渡下、釣提灯八居宅近辺出火之節表釣置、 箱提灯 - 弓張提灯八、御用之時、夜分往来之節、相用ひ、非常 札之儀八、非常之節、持参馳付候様、御役所役人中被仰渡候 時、御請ヶ上度奉伺、右之趣御聞届ヶ被成下候八、難有奉存候、

以上、天保十四卯年六月廿日

先代当主の引退を受け当代当主が「御常式御指物御用」を受け継 いだとあり、前節で推定した臨時御用から「常式御用」(定式御用と 同義）への立場変化が確認される。そして「御役所役人中」から「御 提灯・非常札」が「其侭御渡下」され、「釣提灯」は近辺出火の折に 「表釣置」、箱提灯」や「弓張提灯」は「御用」のため「夜分往来」 の際に使用、「非常札」は非常時に御所一「馳付」の際に持参を仰せ 渡されたのであるが、これは「常式御用」を務めるがゆえと読める。 そして天保 14 年 6 月 20 日に町奉行所へ上記文書で報告、「御聞届ヶ」 を願ったのであり、許された後に以下の「御請書」を再び提出した。

御用之書記有之候

釣提灯壱張

箱提灯壱張

弓張提灯壱張

非常札壱枚

右者私太兵衛義、御所様江御出入仕、御常式御指物御用相勤候 二付、書面之通御提灯非常札共頂戴罷在候処、及老年相勤退身 仕、私義相続仕、右御用是迄之通私江被仰付相勤候時、右提灯 非常札共其侭御渡下、釣提灯八居宅近辺出火之節表釣置、箱提
灯 - 弓張提灯八御用之時、夜分往来之節相用ひ、非常札之儀八、 非常之節持参馳付候様御役所役人中归被仰渡候時、御請ヶ上度 奉伺、戻、御聞届被成下、右御提灯御用之外私用二八相用ひ申間 敷候而、火事場之儀八去文化三寅年二月御差出御座候御触有之 趣、皆相守右提灯を持猥二火事場徘徊仕間敷之旨、此度右御提 灯・非常札共返上仕候処、又者代替并変宅其外等之儀有之節八 其時々御届可申上旨被仰渡候趣、急度相守可申候、依之御請取 奉差上候、以上

町奉行所は御用提灯の許可に際し、「火事場」に持ち込まないよう 命じたことが分かるが、これと同様の内容を触れた町奉行所の触書 は寛延 3 年（1750）、明和 8 年（1771）10 月、文政元年（1818） 2 月にも確認され注13)、船屋に限った内容ではない。また同様の相続 は『船屋太兵衛家文書』では文政 8 年（1825） 7 月 1 日付の「乍恐 口上書」にも読み取れるが、それには、それまで相続時に御所と町 奉行所への相続許可申請を行っておらず、御所役人から召喚され申 請履行を命じられたとある(「私共心得違仕、代替之儀御届不申上候 処、此度御所表江召出御提灯御改（略）是迄代替り $\mathbf{D} \mathbf{0}$ 其外所替之 度御届不申上、不垛之断、以来入念可申旨、被仰渡」)。その時の「御 請書」の日付が翌文政 9 年（1826）2 月 8 日まで遅れるのは、町奉 行所の許可が遅れたことを示しており、その際に町役人へ西町奉行 所一の同行が命じられたのも(「西御役所江町役付被召出」)、町役人 に責任を連帯させたことが窺えるが、安永 9 年（1780）2 月 24 日付 の西町奉行所宛「乍恐口上書」には、以下の内容が記されている。

一、御用と書記候

釣提灯壱張、箱提灯壱張、弓張提灯壱張

右者私前 $/$ 归禁裏御所様江指物御用調達候二付、右御提灯頂戴 仕罷在候、尤右御提灯頂戴仕候砌、御役所江御断申上置候様、 父太兵衛归承伝へ罷在候得共、父太兵衛右御提灯頂戴仕置死去 仕候二付、年月等控無御座候故、相知孔不申候得共、只今二而も 私所持仕候間、御所様御用之節相用ひ罷在候、右之際二 $\mathbf{D}$ 殿 宜敷相認〉被下候、西堀川出水下佃舟屋太兵衛

安永 9 年（1780）の時点で死去している「父太兵衛」は、文政 8 年（1825）引退の太兵衛の父親である可能性が高い。そして「父太 兵衛」からは相続時に許可申請の必要を聞かされていたが、死去時 点で「年月等控無」、おそらく拝領時期等が不明であったため、申請 しないまま「御所样御用之節」に用い続けたとの経緯が読み取れる。

それでは、船屋太兵衛が御所から御用提灯と非常札を付与された のは何時か。天保 14 年の「乍恐口上書」には「常式御用」の代替と 読み取れたが、修理職方江指上候一札写」に、その経緯が記される。 此度、私願之通、御用御提灯拝領被為仰付、難有仕合奉存候、 尤被為仰付候通、平生御用之砌、又者非常罷在候節、是又私居 宅近辺出火等二付表二釣リ申候、外一切私用相用申間敷候、右御 提灯御威光を以、往来之人二対し横柄構敷 $\mathbf{\square}$ 之仕形仕間敷候、 勿論、私用事有之、代少者差上ヶ候共、右之趣常々得と申仕 置、火元一堅持参為致間敷（略）

明和 4 年（1767）4月 2 日に町奉行（「御奉行様」）へ提出された 文書であるが、表題から御所の「修理方役所」へ提出した文書の写 しと分かる。そうすると当該史料が現存するのだから、上記安永 9 年 2 月 24 日付の西町奉行所宛「乍恐口上書」に「年月等控無」と記 し相続許可申請の不履行の理由とした事と整合しない。また明和 4 
表 1 「諸役御免除之分」から抜粋した工芸職人

\begin{tabular}{|c|c|c|c|}
\hline 1 & 烏帽子師 & 室町福永町 & 杉本美作守 \\
\hline 2 & 筆屋 & 室町福永町 & 筆屋長門 \\
\hline 3 & 御筆御用 & 河原町一ノ船入町 & 法橋祏以 \\
\hline 4 & 䈌御用 & 南御霊町 & 䇴屋甚右衛門 \\
\hline 5 & 織物師 & 大北小路東町 & 野本久右衛門 \\
\hline 6 & 戸屋主役 & 烏丸通一条上ル北半町 & 蒔田左京 \\
\hline 7 & 御装束御用 & 鳥丸通桜馬場北半町 & 高田出雲 \\
\hline 8 & 荒物御用 & 十如町 & 荒物屋市助 \\
\hline 9 & 呉服御用 & 室町通武衛陣町 & 八文字屋善兵衛 \\
\hline 10 & 御只服御用 & 室町通御池上儿町 & 三井三郎右衛門 \\
\hline 11 & 御呉服御用 & 衣棚御池上儿町 & 同人 \\
\hline 12 & 御簘御用 & 烏丸通少将井町 & 御笠屋徳助 \\
\hline 13 & 御策御用 & 冨小路通大炊町 & 御笠屋屋理 \\
\hline 14 & 絹御用 & 東洞院通三本木四町目 & 羽二重屋五左衛門 \\
\hline 15 & 御経師 & 室町通白楽天町 & 大経師内匠 \\
\hline 16 & 御絵所 & 室町通鯉山町 & 法橋了玩 \\
\hline 17 & 御障子張 & 烏丸通六角下ル町 & 経師屋久兵衛 \\
\hline 18 & 御障子張 & 烏丸通綾小路下ル町 & 経師庄兵衛 \\
\hline 19 & 御畳師 & 烏丸通六角下ル町 & 伊阿弥筑後 \\
\hline 20 & 御畳師 & 油小路通六角下ル町 & 伊阿弥筑後 \\
\hline 21 & 御畳師 & 烏丸通御池上儿町 & 大針丹後 \\
\hline 22 & 御蚊帳師 & 三条通弁慶町 & 蚊帳や又左衛門 \\
\hline 23 & 蝓燭御用 & 御幸町通御池上儿町 & 螎燭屋九右衛門 \\
\hline 24 & 御打物御用 & 御池通森之木町 & 重命治兵衛 \\
\hline 25 & 紙漉兄弟部 & 高辻通西洞院東入町 & 橋本平兵衛 \\
\hline 26 & 紙漉兄弟部 & 天使突拔船屋町 & 栂井備前守 \\
\hline 27 & 紙漉兄弟部 & 高辻通油小路東入町 & 湯川庄右衛門 \\
\hline 28 & 紙漉兄弟部 & 同町 & 湯川清次郎 \\
\hline 29 & 紙漉兄弟部 & 同町 & 城戸又右衛門 \\
\hline 30 & 紙漉兄弟部 & 西洞院通松原上ル町 & 岡本庄五郎 \\
\hline 31 & 小細工御用 & 大宮通三条上儿町 & 大工作左衛門 \\
\hline
\end{tabular}

表 2 「寄宿御免除之分」から抜粋した工芸職人

\begin{tabular}{|c|c|c|c|}
\hline 1 & 備後表御用 & 油小路通薬屋町 & 備後表九郎左衛門 \\
\hline 2 & 結花御用 & 一条通広橋殿町 & 結花屋庄左衛門 \\
\hline 3 & 木具御用 & 一条通広橋殿町 & 木具屋七郎右衛門 \\
\hline 4 & 木具御用 & 烏丸通三条殿町 & 木具屋又左衛門 \\
\hline 5 & 木具御用 & 鳥丸通川端町 & 木具屋孫左衛門 \\
\hline 6 & 木具御用 & 烏丸通一条上ル北半町 & 木具屋久右衛門 \\
\hline 7 & 木具御用 & 烏丸通一条上ル南半町 & 木具屋源四郎 \\
\hline 8 & 桶之御用 & 出水通中出水町 & 桶屋藤兵衛 \\
\hline 9 & 御蒔絵御用 & 相国寺鹿苑院門前東町 & 小幡七之助 \\
\hline 10 & 御畳紙屋 & 下長者町通藪之内町 & 城殿和泉 \\
\hline 11 & 御鏡屋 & 松之下一条下ル町青平左衛門 & 青平左衛門 \\
\hline 12 & 御塗物御用 & 鳥丸通手洗水町 & 塗師源助 \\
\hline 13 & 御仏師 & 寺町通二条下ル町 & 大仏師蔵之丞 \\
\hline 14 & 御釜御用 & 三条通窵座町 & 釜屋信濃 \\
\hline
\end{tabular}

年に船屋が「御用御提灯洋領」を願い出て拝領したのだから、文政 8 年や天保 14 年の相続関係文書と整合するには、その時点で「常式 御用」に変わったことになる。ところが前掲、仙洞御所役人宛「乍 恐奉申上口上書」（第 2 節）は、明和 4 年から 8 年が経過した安永 4 年でも臨時御用と記していたし、「禁裏御所様御用代銀高」(第 2 節) の取引額も明和 4 年に増えた様子はない。史料では「御道具木地方 御用」を主張した文化 4 年 8 月の「年恐口上書」に常式（定式）御 用になっていた可能性を読夕取れるだけなので (第 3 節)、現時点で は安永 4 年〜文化 4 年の 32 年間に立場変化を指摘するにとどまる。
以上、幕初から二条城近くで指物師を営んでいた船屋太兵衛家は、 17 世紀後半までに御所修理方役所での入札資格を得、臨時御用を務 めるようになり、明和 4 年（1767）には禁裏御所から御用提灯と非 常札を付与された。それから御所御用と共に提灯や非常札も相続を 繰り返したのであるが、文化 4 年 (1807) までに定式御用になった。

その理由として、あるいは安永 3 年（1774）の御所役人処分と共 に定式御用であった指物師が連座処分され、船屋の重用が始まった 可能性もあるが、裏付けは得られない。ただし、この点に関して、 『京都御役所向大概覚書』注14) の「五十 諸役寄宿御免許之事」よ り、享保元年 (1716) 当時に工芸職人の役割で御所御用を務め、「諸 役免除」や「寄宿免除」(第 1 節）を許されていた者、いわゆる御所御 用達をさがすと、表 1 と表 2 のようになる。まず表 1 に、町人義務 のうち公役を免除される諸役免除の工芸職人をみると、多様ながら 指物師の存在は明確でなく、№.31「小細工御用」の大工 1 人に可能性 をみる程度である。続いて表 2 に、町人義務のうち寄宿受入れ義務 だけを免除された工芸職人をみると、N $0.3 〜$ N 0.7 に小具御用」、№.8 に「桶之御用」がある。このうち木具御用は「木具屋」が集団をなし ているが、『角川古語辞典』には「木具」が「白木のままの膳や椀、贅 沢な調度品」とあり、指物の中でも高度な工芸品を报っていた者と考 えられる。そうすると彼らが安永 3 年の御所役人の処分に連座して いれば船屋の重用もあり得るが、想像の域を出ない。それよりも『船 屋太兵衛家文書』には、安政 4（1857）10月の年記で、明確に木具 屋と船屋の関係を示寸以下の「乍恐奉願口上書」が残されている。

私方前々归御所様御船指物御用相勤罷在候処、此度木具指物職 之もの仲ヶ間調立取締之義、当御役所様江奉願書付上ヶ置候様 被仰渡之趣二而、私儀右仲ヶ間立御願之内江加候様、中之惣代 室町一条上儿町木具屋新右衛門外二人归掛合有之候得共、私方 之儀者、船指物細工おも二而、私方同家并別家下職之もの別紙 之通有之、御用向之節者右同家并下職者江も申付、細工致御用 品調進仕罷在候儀二而此度仲ヶ間立掛願奉申上罷在候もの八御 所様木具職御用相勤罷在りもの二而、私方職柄共違ひ、木具職 又者箱指物細工等致候もの方奉公人等、私方職向二相違ひ候儀 も無之、細工之事柄違ひ候儀二付、右之もの仲ヶ間立御願之内 江加少可申義者差除ヶくれ候様、右惣代之者共江返答置申候、 右之仕合二而私共別紙同家下職之もの十六人儀者、右仲ヶ間立 請願之内江者加少不申間、乍恐此段御断奉申上候、御憐憫を以 右之趣聞届被成下候八、如何斗難有可奉存候、以上

西堀川出水町 御船指物師 船屋太兵衛

西堀川竹屋町上町 船屋平兵衛

千本一条上町 檜本屋弥兵衛

西堀川上長者町上町 船屋伊兵衛

同町 船屋市兵衛

同町 大黒屋弥兵衛

西堀川中立売上儿町 船屋卯兵衛 下長者町猪熊出合町

千本中立売上 $/$ 町 夷川御峰町角

万寿寺烏丸東入町 同町 万寿寺町高倉西入 $/$ 町
柳屋庄兵衛 松屋佐兵衛 井筒屋庄太郎 漆屋七右衛門 津国屋嘉兵衛 漆屋喜兵衛 


\section{東洞院仏光寺下ル町 \\ 鳥丸四条通下町 \\ 建仁寺町五条下N武丁目 \\ 建仁寺松原上町 \\ 近江屋市兵衛 \\ 近江屋吉兵衛 \\ 山城屋卯兵衛 \\ 井筒屋六兵衛}

安政 4 年 (1857) に、木具屋新右衛門ら「木具指物職」の者が「仲 ヶ間」組織結成を町奉行所に届けたとある。どのような仲ヶ間組織 を目指したのかは明らかでないが、幕末になっても船屋同様に御所 御用を務める木具屋は、船屋太兵衛や親戚筋、下請職人 ( 「同家并別 家下職」）の取り込みを目論んだのである。これに対し船屋は「船指 物細工」が自分達の主な仕事であり、「木具指物職」の木具屋とは「職 柄」が違うと主張し加わらないとした。もつともこれは『船屋太兵 衛家文書』に調度類や消防道具など多様な工芸品の史料がある事と 整合せず、むしろ木具屋とは御所御用に重なる部分があって競争関 係にあった筈である。そうすると木具屋が船屋を同じ仲ヶ間に取り 込もうとした目的は、御所との関係においては、16〜17 世紀前半に 遡る 注15) 寄宿免除の木具屋は提灯付与の船屋よりも上格だから、ち ようど御用砂子屋が庶民相手の平砂子屋に対し優位であり続けて御 所・幕府相手の仕事を独占したように注16)、御所御用における競争 を否定して木具屋に有利な業務分担を目指した可能性もある。

ここで表 2 から読み取る享保元年当時の寄宿免許の木具屋を○で、 また船屋に加入を㗢きかけた木具屋新右衛門の居住地をえで地図に プロットすると、図 2 にみるように烏丸通、特に御所北西に集まっ ているが、貞享 2 年 (1685) の『京羽二重』注17)では少し南下寸る 鳥丸通の下立売から二条通に「長文庫・挟箱」が記されている。

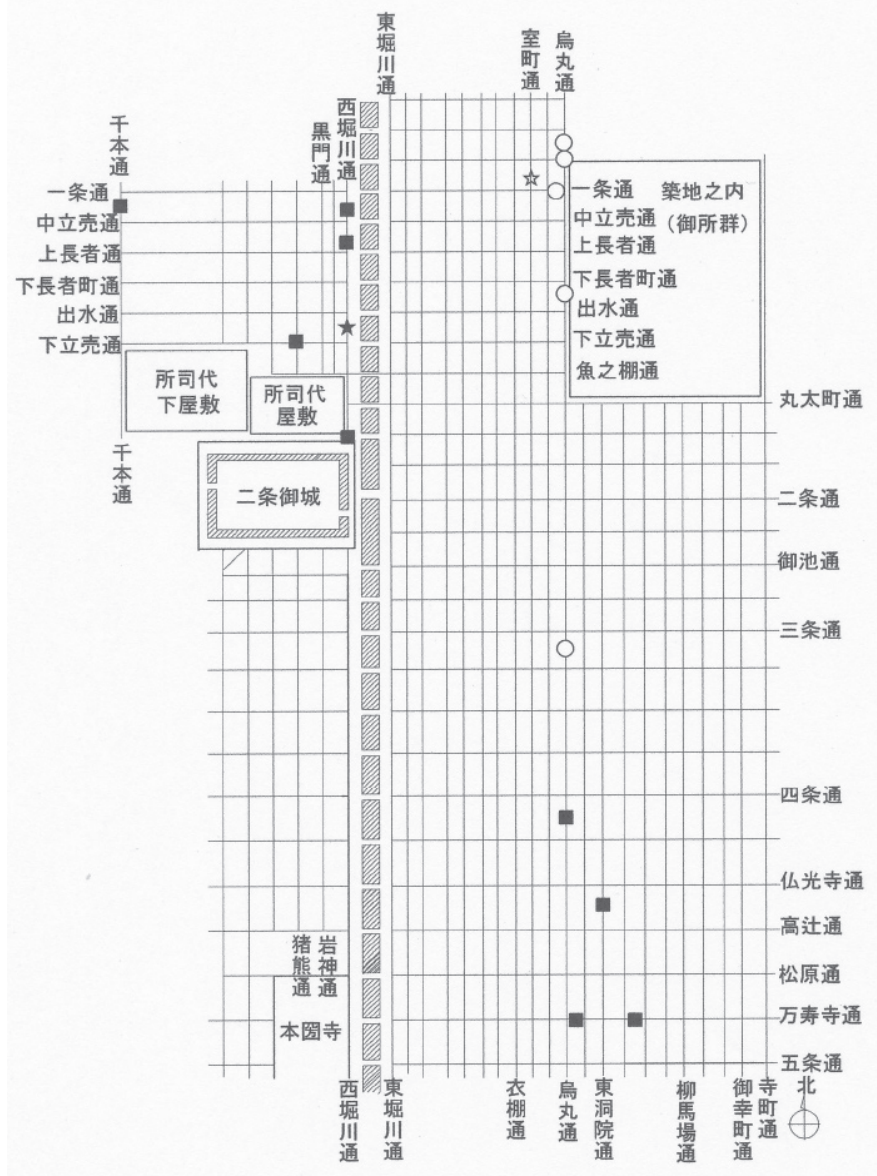

図 2 幕末の船屋らと享保元年当時に寄宿免除の木具屋の位置
これに対し「乍恐奉願口上書」より船屋太兵衛家をれ、親戚や下請 職人をロでプロットすると（建仁寺に近い鴨東の 2 軒省略）御所か ら離れている。水舟を扱い川から離れられなかったのかというと、 川から遠い万寿寺通沿いにも 2 軒のロがあり、『京羽二重』も同地に 「井筒・はしり・水船」と記す。よって図 2 から読み取れるのは、 江戸時代初期から木具御用を務めて木具屋を名乗り、寄宿免除を許 されるなどしていた指物師は、御所近くに集まって居住し、江戸時 代を通じて御所と深い結び付きがあった。これに対し元々は水船を 扱って船屋を屋号とした船屋太兵衛らは、居住地も御所から離れて おり、幕初には御所との関係も密接ではなかった可能性が高い。

\section{5. 本論のまとめ}

本論は、多くの工芸職人が日本の伝統的な建築空間を支えたと考 えて、指物師と御所の関係を『船屋太兵衛家文書』に検討した。

京都の工芸職人に関する先行研究は、幕府や御所相手の御用砂子 屋が庶民相手の平砂子屋を仲ヶ間に取り込み優位であり続けた事を 指摘した。これに対し本論は、17 世紀前半から二条城近くに居住、 元々は水舟を扱い、船屋を屋号とした指物師が、17 世紀後半には御 所御用の入札資格の得、臨時御用から随時受注の定式御用へ、また 御用提灯や非常札も付与されるなど、江戸時代を通じて京都特有の 顧客である御所との関係を深めていき、幕末には御所近くに居住し 寄宿免除を許され、御所相手の指物師では上格の木具屋も無視でき ない存在になったことを明らかにした。もっともこのためには、水 舟以外の指物も扱い、木具屋との競争に耐えうる技術を獲得し、価 格面でも競争に打ち勝つ努力が必要であったはずである。そこで次 論以降でも『船屋太兵衛家文書』から、その経緯や船屋が扱った指 物の内容、価格、他の工芸職人の関係などを明らかにしていきたい。

注

注1）川本重雄：寝殿造の空間と儀式，中央公論美術出版，2005

注2）伊藤ていじ：聞書・日本建築の手わざ, 第 1 巻, 堂宮の職人, 平凡社、 2000，日向進：近世京都の町・町家・町家大工，思文閣出版，1998

注3）永田恵子・岡本真理子 - 河田克博 - 麓和善 - 仙田満 .内藤昌 : 建築系 道具雛形の基本型と発展型, 建築書系道具雛形の歴史的変遷, 日本建 築学会計画系論文集，第 539 号，2001.1、同様各氏のほか高木真人： 建築書系道具雛形の設計学理, 道具設計における寸法体系, 日本建築 学会計画系論文集, 第 557 号, 2002.7

注4） 虎屋の五世紀，伝統と革新の経営，株式会社虎屋，2003

注5）資料館紀要，第 11 号，京都府立総合資料館，1983

注6）安道永: 近世京都における絵師の居住動向, 日本建築学会計画系論文 集，第 75 巻，第 654 号，2010.8

注7）資料館だより，第 152 号，2007.7

注8）杉森哲也：江戸時代の聚楽第跡，豊臣秀吉と聚楽第，文理閣，2001

注9）新修京都叢書，第一巻，光彩社，1967

注 10）新修京都叢書, 第六巻, 光彩社, 1968

注11）丸山俊明: 京都の町家の軒先板に関する再検討, 日本建築学会計画系 論文集，634 号，2008.12、同：江戸時代後期の二条番衆の寄宿形態, 日本建築学会計画系論文集，第 640 号，2009.6

注12） 谷直樹：中井家大工組支配の研究，思文閣出版，1992.2

注13）京都町触集成，第 12 巻，p24，岩波書店，1987、ほか。

注14）清文堂史料叢書, 第 5 刊, 京都御役所向大概覚書, 清文堂, 1973

注15）上掲, 京都御役所向大概覚書, 五十, 諸役寄宿御免許之事上り「諸役 免許之初者後陽成院御治世帅初栩以前者寄宿免許計」とある。

注16）前掲，資料館紀要，第 11 号

注17）新修京都叢書，第六巻，光彩社，1968 